\title{
The Influence of Website Service Quality towards Consumer Satisfaction by Using Webqual 4.0 Method: Study on Grab Users in Bandung
}

\section{Febri Hikmah Haryanti ${ }^{1}$ and Retno Setyorini ${ }^{2}$}

\author{
${ }^{1}$ Telkom University, Indonesia, e-mail: febrihikmah5@gmail.com \\ ${ }^{2}$ Telkom University, Indonesia, e-mail: retnosrini@telkomuniversity.ac.id
}

\begin{abstract}
This research is motivated by rapid technological developments to create business opportunities through technology increasingly. The website becomes important as platforms deliver information to users in a wide range of information about a company (company profile) until the customer service. One current trend is a provider of transportation services online. Grab as one based transportation services provider online service accessible websites for consumers to support services offered to costumers. This study aims to determine the quality of the website Grab customer satisfaction. Based on the type of research, including research into the types of causality research. Sampling technique in this study is using purposive sampling technique and the number of samples in this study as many as 100 respondents to the people who live in Bandung and ever used website Grab.
\end{abstract}

Keywords: Service Quality, Consumer Satisfaction, Website Grab.

\section{Introduction}

Technological developments the last few years is so fast, creating business opportunities through technology more promising. People create technology to encourage or support activities conducted by individuals and companies to be more effective and efficient (Ahmad, 2015). In the world, Internet user growth from year to year has increased to 200 million users from 2015 and then, according to the report State of Connectivity: A Report on the Global Internet Access created by Facebook which means there are now about 3.4 billion internet users in the world. See from the human population has reached 7.4 billion. It means, that the internet has been almost used by 50 percent population of Earth.www.techno.id.www.internetworldstats.com. According to information, www.internetworldstats.com shows the percentage of Internet users in the world that consists of 7 (seven) of the continent in 2016. From this figure, most users come from Asia at $49.6 \%$ increased $1.8 \%$ compared to $201547.8 \%$. It is influenced by the rise of Asia as the main contribution to the internet population in the world. Indonesia into the top 10 with ranks to 6 (six) in the world in terms of Internet users. The population of Internet users in Indonesia is growing very rapidly. WeAreSocial Based on published data, there are now 88.1 million people in Indonesia who use the internet from a total population of 259 million people. Data quoted from Digital, Social, and Mobile Report in 2016, explained that the active user in Indonesia increased by 15 percent than in January 2015. Activities were made public in various kinds of Internet usage. According to data from the Association of Indonesian Internet Service Provider (APJII) shows the activity of searching for information is located on the second position after using social networking activity that is equal to $68.7 \%$. Percentage looking information is not much use of social networking. However, this is an opportunity for businesses to provide information to market products and services they have through the website. The website often called Web or www (world wide web), can be interpreted a collection of pages that display various kinds of information text, data, images or motion, animation data, voice, video or a combination of all of them, whether it's nature static and dynamic. The growth of Information Technology (IT) is growing rapidly led to the emergence of various websites and make the website as an integral part of an organization or company in terms of service for users. One current trend is a provider of transportation services online. Grab is one of the online-based transportation services providers. Indonesia has become the best market for service providers-based transportation 
applications. Grab Indonesian company has a website service that serves as a medium for providing information to consumers about what services they are selling.

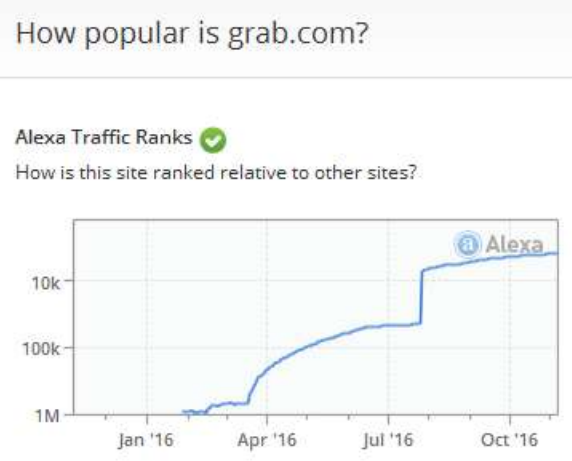

Figure 1. Graph Website Grab Visitors

In the picture above can be explained that according to alexa.com is an amazon.com site belongs to collect data such as users in the internet surfing habits and sends it to Alexa data center, where the data is stored and analyzed, so that became the basis of web traffic reports provided by the company to its customers shows that the website visitors Grab decreased each month. In November 2016 the number of visitors was under 10 thousand in which it declined in the last 3 months. In this study the authors conducted a preliminary survey of 30 respondents to the service users on the website Grab any obstacle that most felt by users of the service website Grab. From the result of the declining number of visitors and several complaints were still being felt by consumers who use the services website Grab, then the Grab needs to improve the services of the website. Because the service is perceived to have an impact on customer satisfaction. Therefore, to achieve customer satisfaction, quality service is the key to customer satisfaction measurement. Kotler and Keller (2012: 37) say "If the product's or service performance falls short of expectations, the customer is dissatisfied. If performance matches expectations, the customer is satisfied. If performance exceeds expectations, the customer is highly satisfied or delighted" which means that if the performance of the product or service falls short of expectations, the customer is not satisfied. If the performance according to expectations, the customer is satisfied. If performance exceeds expectations, the customer is very satisfied or pleased. Previous research has suggested that service quality directly affects customer satisfaction and customer satisfaction with the website have a positive impact (Billy Bai, 2008, Chen and Cheng, 2009). Barnes and Vidgen (2001) had been claimed that the quality of website services can only be seen from a consumer standpoint.

Service Quality. Tjiptono (2011:59) says that the service quality is the expected level of excellence over the level of excellence to meet consumer desires. According Pujawan (2011:97) defines service quality as a result of the perception and compare between consumer expectations with the actual performance of services there are two main factors that affect the service quality, which is expected service (experience expected) and perceived service (service received).

Webqual. WebQual methods have been developed since 1998 by Barnes and Vidgen on e-commerce websites and e-government. Barnes and Vidgens (2002) state that WebQual is one method or technique of measuring the quality of a website based on the perception of active users (end user). This method is the development of SERVQUAL is widely used previously on measuring the quality of services in general. WebQual based on the concept Quality Function Development (QFD) is "structured and disciplined process that Provides a means to identify and carry the voice of the customer through each stage of product and or service development and implementation" which can be interpreted as a structured process and disciplined serving means to identify and bring the voice of the consumer through every stage of the development and implementation of a product or service. 
WebQual has experienced interactions in the preparation and grain dimension statement (Barnes and Vidgens, 2002: 114). WebQual version 1.0 was developed in the domain of website business schools in the United Kingdom (UK). Organized a workshop with participants six master students as delegates. The goal in this first development which collects quality criteria in accordance with the object under investigation.

WebQual 2.0 was applied to the website Business to Customer (B2C). The addition of the second development is the quality aspect of interaction with the basic literature mentions that the delivery service is that users interact directly with the service. Dimensional quality of these interactions was developed based on the concept of SERVQUAL and domain online bookstore. At 3.0 WebQual quality indicators are categorized into three categories: quality of the site, the quality of information and the quality of the interaction.

Instruments WebQual 3.0 was applied to an online auction website. WebQual 4.0 variable usability has been greatly expanded, it can be seen in the indicators that put more emphasis on user perceptions rather than the website designer that uses three measurement categories with 22 of the questions. The third category is the usability, information, and service interaction. Usability category is based on the study of the relationship between humans and computers and a study on web usability. Among the ease of navigation, design suitability and images presented to the user. Category information is assessed based on information systems in general. This category relates to the quality of information systems in general. This category relates to the quality of the website content is information for the user's purpose, such as to the accuracy, format, the relevance of the information presented. Category of service interaction related to the interaction of perceived service when users deeply engaged with the website.

Customer Satisfaction. Kotler and Keller (2012:37) say “ If the product's or service performance falls short of expectations, the customer is dissatisfied. If performance matches expectations, the customer is satisfied. If performance exceeds expectations, the customer is highly satisfied or delighted"

Framework. Barnes and Vidgens (2002) state that WebQual is one method or technique of measuring the quality of a website based on the perception of active of users (end user). While consumer satisfaction according to Kotler and Keller (2012: 37) says "If the product's performance falls short of expectations, the customer is dissatisfied. If performance matches expectations, the customer is satisfied. If performance exceeds expectations, the customer is highly satisfied or delighted". WebQual that used is the latest version 4.0 has three measurement categories with 22 questions. The third category is the usability, information and service interaction. Based on the above explanation, the researchers make the framework as shown below: 


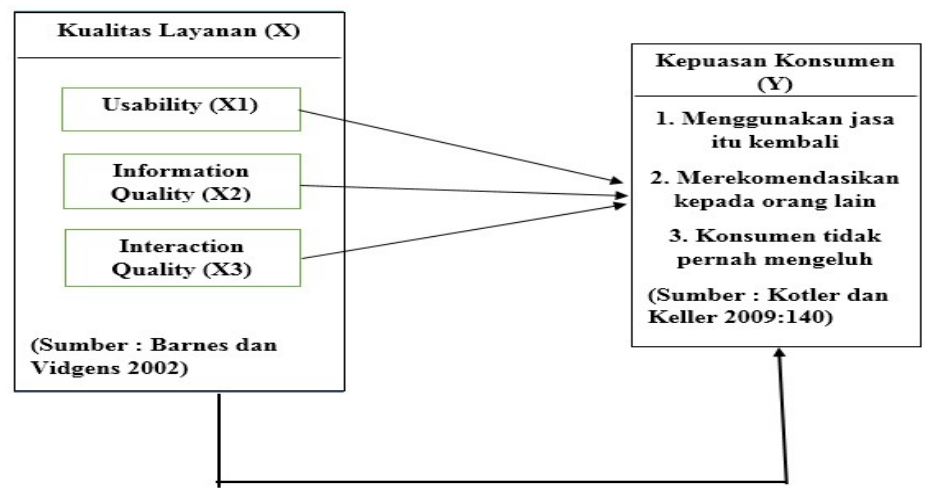

Figure 2. Framework

Based on the framework that has been created, then the hypothesis in this study is "Website Grab service quality effects on consumer satisfaction."

\section{Research Methodology}

The type of research used by the researchers is descriptive and causal research with quantitative methods. According to Sekaran (2011), descriptive research is research to know and be able to explain the characteristics of the studied variables in a situation. The study is to determine the causal relations (Sugiyono, 2012). According Sugiyono (2014) methods of quantitative research is a research method that is based on the philosophy of positivism, is used to examine the population or a particular sample, the sampling technique is generally done at random, data collection using research instruments, data analysis is quantitative or statistical purposes to test the hypothesis that has been set.

Variable research is an attribute or the nature or value of a person, object or activity which may have certain variations defined by the researchers to learn and then drawn conclusions (Sugiyono, 2014). In this research there are two variables:

1. The service quality that acts as the independent variable or also called the independent variable (variable $\mathrm{X}$ ), which is a variable that affects or is the cause of the change or the emergence of the dependent variable (dependent).

2. Consumer satisfaction that acts as the dependent variable also called the dependent variable (Y), which is a variable that is affected, or which become due, because of the independent variables. In this study, methods of solving the object of discussion are determined by setting the variables used to describe the scale of the measured variable (operational variables) into sub-variables, then refer to these variables was developed to be an indicator of each variable.

Methods of data collection conducted by the authors are as follows:

a. Observation

In this study, the preliminary observations made to determine any matter contained in the quality of service that is the way to understand the transport phenomena online observed up and down the number of visitors is on alexa.com database during the last 3 months and supported by information based on previous research using the same method. Furthermore, the authors conducted a test by spreading the initial questionnaire to determine what barriers are there.

b. Questionnaires

According to Sugiyono (2014: 142), the questionnaire is a technique of data collection is done by giving a set of questions or statements in writing to the respondent to answer. In this study, questionnaires were distributed to 100 respondents online that contains 25 questions with answer options used are from strongly agree (SS) to strongly disagree (STS) or in scale intervals ranging score 1-5. 
c. Library Studies

Literature study in this research is to find information related to the research by reading books, national and international journals, and thesis.

\section{Result and Discussion}

Table 1. Respondents Regarding Service Quality Website Grab (X)

\begin{tabular}{|l|c|c|}
\hline $\begin{array}{l}\text { Dimensions } \\
\text { Variable }\end{array}$ & $\begin{array}{c}\text { Average } \\
\text { Score } \\
\text { Total }\end{array}$ & $\begin{array}{c}\text { Average } \\
\text { Percentage }\end{array}$ \\
\hline $\begin{array}{l}\text { Usability } \\
\left(X_{1}\right)\end{array}$ & 369 & $73,8 \%$ \\
\hline $\begin{array}{l}\text { Information } \\
\text { Quality }\left(X_{2}\right)\end{array}$ & 378 & $75,6 \%$ \\
\hline $\begin{array}{l}\text { Interaction } \\
\text { Quality }\left(X_{3}\right)\end{array}$ & 370 & $74 \%$ \\
\hline \multicolumn{2}{|c|}{ Average Score Total } & 372,33 \\
\hline \multicolumn{2}{|c|}{ Average Percentage } & $74,6 \%$ \\
\hline
\end{tabular}

Source: Questionnaire Results Data Processing

Based on the table above can be seen that the average score of the total respondents to the dimensions of Usability $\left(X_{1}\right)$ amounted to 369 , or $75.8 \%$, which means that the dimension Usability $\left(X_{1}\right)$ is in a category agreed and included into the good category. The dimension of Information Quality $\left(X_{2}\right)$ has an average total score of 378 , or $75.6 \%$, which means that the dimensions of the Information Quality $\left(X_{2}\right)$ are in a category agreed and included into the good category. Dimension Interaction Quality $\left(X_{3}\right)$ have an average total score of 370 , or $74 \%$, which means that the dimension Interaction Quality $\left(X_{3}\right)$ are in a category agreed and included into the good category.

Multiple Linear Regression Analysis. Based on the results of the regression analysis calculated using IBM SPSS version 21 can be arranged table as follows:

Table 2. Results Multiple Linear Regression Analysis

\begin{tabular}{|c|c|c|c|c|c|c|c|}
\hline & & & Coefficien & & & & \\
\hline \multirow[t]{2}{*}{ Model } & \multicolumn{2}{|c|}{$\begin{array}{c}\text { Unstandardized } \\
\text { Coefficients } \\
\end{array}$} & \multirow{2}{*}{$\begin{array}{c}\text { Standardized } \\
\text { Coefficients } \\
\text { Beta }\end{array}$} & \multirow[t]{2}{*}{$t$} & \multirow[t]{2}{*}{ Sig. } & \multicolumn{2}{|c|}{ Collinearity Statistics } \\
\hline & B & $\begin{array}{l}\text { Std. } \\
\text { Error }\end{array}$ & & & & Tolerance & VIF \\
\hline (Constant) & ,790 & .491 & & 1,609 & 111 & & \\
\hline Usability &, 315 & ,123 & 245 & 2,561 & 012 & 672 & 1,488 \\
\hline $\begin{array}{l}\text { Information } \\
\text { Quality }\end{array}$ & -099 &, 129 & -085 &,- 765 & .446 & .495 & 2,018 \\
\hline $\begin{array}{l}\text { Interaction } \\
\text { Quality }\end{array}$ & .636 & .129 &, 540 & 4,949 & , 000 &, 518 & 1,931 \\
\hline
\end{tabular}

a. Dependent Variable: VAR00004

Source : Data Processing SPSS IBM version 21

Based on the calculations and multiple linear equation above is:

$$
\mathrm{Y}=0,790+0,315 X_{1}-0,099 X_{2}+0,636 X_{3}
$$

Multiple linear regression equation can be explained as follows:

a. Constants $(\alpha)=0.790$. It shows a constant value if the variable WebQual (X) consisting of Usability, Information Quality and Interaction Quality $=0$, consumer satisfaction on service quality website Grab fixed at 0.790 . 
b. Usability regression coefficient $\left(\mathrm{X}_{1}\right)=0.315$. This indicates that the variable Usability positive effect on consumer satisfaction, or in other words, if the variable Usability is increased by one unit, then consumer satisfaction will increase by 0.315 .

c. The regression coefficient Information Quality $\left(\mathrm{X}_{2}\right)=-0.099$. This indicates that the variable Information Quality negatively affect consumer satisfaction or in other words, if the variable Information Quality is increased by one unit, the consumer satisfaction will be reduced by 0.099 .

d. The regression coefficient Interaction Quality $\left(\mathrm{X}_{3}\right)=0.636$. This indicates that the variable Interaction Quality positive effect on consumer satisfaction, or in other words, if the variable Interaction Quality is increased by one unit, then consumer satisfaction will be increased by 0.636

Table 3. Coefficient of Determination Model Summary

\begin{tabular}{|c|c|c|c|c|}
\hline Model & $\mathrm{R}$ & $\begin{array}{c}\mathrm{R} \\
\text { Square }\end{array}$ & $\begin{array}{c}\text { Adjusted } \\
\mathrm{R} \text { Square }\end{array}$ & $\begin{array}{c}\text { Std. The } \\
\text { error of the } \\
\text { Estimate }\end{array}$ \\
\hline 1 & $\begin{array}{c}, 639 \\
\mathrm{a}\end{array}$ &, 409 &, 390 &, 62687 \\
\hline
\end{tabular}

The coefficient of determination ( $\mathrm{R}$ Square) showed a value of $40.9 \%$, meaning that this value indicates that the variable quality of service consisting of Usability, Information Quality, and Interaction Quality have an impact on consumer satisfaction variable $40.9 \%$ and the remaining $59.1 \%$ influenced other factors not examined in this study.

Table 4. Results of Hypothesis Testing (F-test)

ANOVA $^{\mathrm{a}}$

\begin{tabular}{|l|r|r|r|c|c|}
\hline Model & Sum of Squares & df & Mean Square & F & Sig. \\
\hline Regression & 26,062 & 3 & 8,687 & 22,107 &, $000^{b}$ \\
Residual & 37,725 & 96 &, 393 & & \\
Total & 63,786 & 99 & & & \\
\hline
\end{tabular}

From table 4. it is known that the value of $\mathrm{F}=22.107$ so that it meets the criteria accepted $\mathrm{H}_{1}$ Fhitung $22.107>$ Ftabel and the Sig. $0.000<0.05$. It can be concluded that there are significant simultaneously (simultaneous) between the dimensions of service quality website Grab is Usability, Information Quality and Interaction Quality on consumer satisfaction.

Table 5. Partial Results of Hypothesis Testing (T-test)

\begin{tabular}{|l|c|c|c|c|c|}
\hline Model & \multicolumn{2}{|c|}{ Unstandardized Coefficients } & Standardized Coefficients & $\mathrm{t}$ & Sig. \\
\cline { 2 - 4 } & $\mathrm{B}$ & Std. Error & Beta & & \\
\hline (Constant) &, 790 &, 491 & & 1,609 &, 111 \\
VAR00001 &, 315 &, 123 &, 245 & 2,561 &, 012 \\
VAR00002 &,- 099 &, 129 &,- 085 &,- 765 &, 446 \\
VAR00003 &, 636 &, 129 &, 540 & 4,949 &, 000 \\
\hline
\end{tabular}

The results of the partial test (t-test) can be summarized as follows:

1. Variable Usability $\left(\mathrm{X}_{1}\right)$ 
Based on the analysis data obtained $t$ value for the variable Usability $t$ count $=2,561>t$-table 1.985 and a significance value (sig.) Amounted to $0.012<\alpha=0.05$, then $\mathrm{H}_{0}$ rejected and $\mathrm{H}_{1}$ accepted so that we can conclude there is significant partial Usability significantly to consumer satisfaction.

2. Variable Information Quality $\left(\mathrm{X}_{2}\right)$

Based on the analysis data obtained $t$ value for the variable Information Quality t-test $=-0.765$ are among the t-table value (-1.985 and 1.985) and a significance value (sig.) Of $0.446>\alpha=0.05, \mathrm{H}_{0}$ accepted and $\mathrm{H}_{1}$ rejected so we can conclude that there is no significant influence of the independent variable on the dependent variable.

3. Variable Interaction Quality $\left(\mathrm{X}_{3}\right)$

Based on the analysis data obtained $t$ value for the variable Information Quality $t$ count $=4,949>t$ table 1.985 and a significance value (sig.) $0,000<\alpha=0.05$, then $\mathrm{H}_{0}$ rejected and $\mathrm{H}_{1}$ accepted so that we can conclude there is significant partial information Quality significantly to consumer satisfaction. Analysis of partial effect is used to determine how much influence the independent variable on the dependent variable. Here are the results of partial correlation analysis based on processing SPSS version 21 can be seen in Table 6 .

Table 6. The Amount of Influence Partial

\begin{tabular}{|c|c|c|c|c|}
\hline \multirow[t]{2}{*}{ Variable } & $\begin{array}{l}\text { Standardized } \\
\text { Coefficients }\end{array}$ & Correlations & \multirow[t]{2}{*}{$\begin{array}{l}\text { The Amount of } \\
\text { Influence Partial }\end{array}$} & \multirow{2}{*}{$\begin{array}{c}\text { The Amount of } \\
\text { Influence Partial } \\
(\%)\end{array}$} \\
\hline & Beta & Zero-order & & \\
\hline Usability $\left(\mathrm{X}_{1}\right)$ & 0,245 & 0,473 & 0,115 & $11,5 \%$ \\
\hline $\begin{array}{c}\text { Information Quality } \\
\left(\mathrm{X}_{2}\right)\end{array}$ & $-0,085$ & 0,410 & $-0,034$ & $-3,4 \%$ \\
\hline $\begin{array}{c}\text { Interaction Quality } \\
\left(\mathrm{X}_{3}\right)\end{array}$ & 0,540 & 0,607 & 0,327 & $32,7 \%$ \\
\hline \multicolumn{3}{|c|}{ Total Effect } & 0,409 & $40,9 \%$ \\
\hline
\end{tabular}

The magnitude effect of partially obtained by multiplying the standardized beta coefficients of each variable with zero-order. From the table above it can be concluded that the effect of Usability $\left(\mathrm{X}_{1}\right)$ towards consumer satisfaction partially by $11.5 \%$, the effect of Information Quality $\left(\mathrm{X}_{2}\right)$ partially reduced to the satisfaction of $-3.4 \%$, and the influence of Interaction Quality $\left(\mathrm{X}_{3}\right)$ on customer satisfaction by $32.7 \%$. Thus, the total overall effect of Usability $\left(\mathrm{X}_{1}\right)$, Information Quality $\left(\mathrm{X}_{2}\right)$, and Interaction Quality $\left(\mathrm{X}_{3}\right)$ towards consumer satisfaction $(\mathrm{Y})$ is $40.9 \%$.

\section{Conclusion}

From the research results in the previous chapter, and consideration of Service Quality Website Grab Influence on Consumer Satisfaction, the author can write some conclusions that can formulation problem in this research are:

1. Service Quality Website Grab. Based on the research service quality website Grab according to respondents overall rated website services provided well by the respondent. This indicates that the variable service quality such as Usability as design of the website, appearance, ease of use and image delivered to the consumer either, Information Quality as propriety information presented, accuracy and format can be received clearly by consumers, and Interaction Quality is the quality of service to the consumer interaction can manifest a sense of trust.

2. Consumer satisfaction on Service Quality of Website Grab. Based on the results of consumer satisfaction in the service quality website Grab according to respondents showed an overall rated 
excellent by the respondent. This shows that consumers are satisfied with the services provided so that they will access back and recommend to the relatives and families.

3. The Amount of Influence Services Quality Simultaneously on Consumer Satisfaction. Based on the results of simultaneous hypothesis testing, it is known that indicators such as Usability, Information Quality, and Interaction Quality jointly had $40.9 \%$ influence on consumer satisfaction while the remaining $59.1 \%$ is influenced by other factors not examined in this study.

4. The Amount of Influence Service Quality Partially on Consumer Satisfaction. Based on the partial results of hypothesis testing, sub-variable having a significant effect on consumer satisfaction is sub-variable Usability and Interaction Quality Information Quality sub-variable where no significant effect on consumer satisfaction. The greatest amount of influence on consumer satisfaction is sub-variable Interaction Quality by $32.7 \%$, while sub-variable who had the most influence small in the Information Quality of $-3.4 \%$.

\section{References}

Barnes, Stuart \& Vidgen R. (2002). An Integrative Approach to The Assessment of E-Commerce Quality. Journal of Electronic Commerce Research, 3(3), 114-127. UK: University of Bath. http://www.webqual.co.uk/papers/bookstore.pdf [ September 2016].

Barnes, Stuart \& Vidgen R. (2003). Measuring Web Site Quality Improvements: a case study of the forum on strategic management knowledge exchange. International Referred Research Journal Emerald Insight. pp.297-309 [ November 2016].

Bai, Billy (2008). The Impact of Website Quality on Customer Satisfaction and Purchase Intention. International Journal of Hospitality Management. Vol 27 Issue 3 pp 391-401

Kotler, Philip \& Amstrong, Gary. (2009). Manajemen pemasaran. Edisi 13 Jilid 1.Jakarta: Erlangga. Kotler, Philip \& Amstrong, Gary. (2012).Marketing Management 14 Edition, Global Edition.Pearson Prentice Hall.

Riduwan, Kuncoro. (2012). Metode \& Teknik Menyusun Proposal Penelitian. Bandung: Alfabeta,cv Sugiyono. (2011). Metode Penelitian Kuantitatif, Kualitatif, dan R\&D, Cetakan ke 13. Bandung: ALFABETA

Sugiyono. (2012). Metode Penelitian Kuantitatif, Kualitatif, dan R\&D, Cetakan ke 20. Bandung: ALFABETA

Sugiyono. (2014). Metodologi Penelitian Bisnis, Cetakan ke 18. Bandung: ALFABETA

Tjiptono, Fandy \& Chandra, Gregorius. (2011). Service, Quality \& Satisfaction, Edisi 3. Yogyakarta: Andi Offset 